\title{
Micromonospora tulbaghiae sp. nov., isolated from the leaves of wild garlic, Tulbaghia violacea
}

Correspondence

Paul R. Meyers

paul.meyers@uct.ac.za

\author{
Bronwyn M. Kirbyt and Paul R. Meyers
}

\author{
Department of Molecular and Cell Biology, University of Cape Town, Private Bag X3, Rondebosch \\ 7701, Cape Town, South Africa
}

\begin{abstract}
A novel actinomycete, strain $\operatorname{TVU}^{\top}{ }^{\top}$, was isolated from leaves of the indigenous South African plant Tulbaghia violacea. Applying a polyphasic approach, the isolate was identified as a member of the genus Micromonospora. Phylogenetic analysis of the 16S rRNA gene sequence showed that strain TVU1 ${ }^{\top}$ was most closely related to Micromonospora echinospora DSM $43816^{\top}$. However, phylogenetic analysis based on gyrB gene sequences showed that strain TVU1 ${ }^{\top}$ was most closely related to the type strains of Micromonospora aurantiaca and Micromonospora chalcea. DNA-DNA relatedness values between strain TVU $1^{\top}$ and the type strains of $M$. echinospora, M. aurantiaca and $M$. chalcea were $7.6 \pm 4.5,45.9 \pm 2.0$ and $60.9 \pm 4.5 \%$, respectively. Strain $\mathrm{TVU}^{\top}{ }^{\top}$ could be distinguished from the type strains of all three of these species by several physiological characteristics, such as colony colour, $\mathrm{NaCl}$ tolerance, growth temperature range and sole carbon source utilization pattern. Strain TVU1 ${ }^{\top}$ (=DSM $45142^{\top}=$ NRRL B-24576 ${ }^{\top}$ ) therefore represents a novel species for which the name Micromonospora tulbaghiae sp. nov. is proposed.
\end{abstract}

The genus Micromonospora was proposed by Ørskov (1923) and is the type genus of the family Micromonosporaceae Krasil'nikov 1938 emend. Stackebrandt et al. 1997 (Kawamoto, 1989). Distinguishing features of members of the genus Micromonospora include the formation of single, non-motile spores on the vegetative mycelium, which does not fragment, and the absence of aerial mycelium (Kawamoto, 1989). Although the first antibacterial activity by a member of this genus was reported in 1942, it was the isolation of the aminoglycoside gentamicin from Micromonospora purpurea (reclassified as Micromonospora echinospora by Kasai et al., 2000) in 1963 that sparked the widespread screening of this genus for antibiotics (Wagman \& Weinstein, 1980). After Streptomyces, the genus Micromonospora is probably the second most prolific producer of antibiotics (Wagman \& Weinstein, 1980). Micromonosporae appear to be widely distributed in nature and have been isolated from a number of diverse sources, including a Thai peat swamp forest (Thawai et al., 2005), water samples (Trujillo et al., 2005) and Antarctic sandstone

†Present address: Institute for Microbial Biotechnology and Metagenomics, University of the Western Cape, Private Bag X17, Bellville 7535, Cape Town, South Africa.

The GenBank/EMBL/DDBJ accession numbers for the 16S rRNA and gyrB gene sequences of Micromonospora tulbaghiae sp. nov. TVU1 ${ }^{\top}$ are EU196562 and EU434806, respectively.

Unrooted phylogenetic trees based on $16 \mathrm{~S}$ rRNA gene sequences of $\mathrm{TVU}^{\top}$ and all species in the genus Micromonospora and the gyrB gene sequences of selected species in the genus Micromonospora are available as supplementary figures with the online version of this paper.
(Hirsch et al., 2004). Four recently described species are plant endophytes: Micromonospora coriariae was isolated from root nodules of the Mediterranean shrub Coriaria myrtifolia (Trujillo et al., 2006); Micromonospora lupini and Micromonospora saelicesensis were isolated from root nodules of the Mediterranean shrub Lupinus angustifolius (Trujillo et al., 2007); and Micromonospora pisi was isolated from root nodules of a pea plant, Pisum sativum (Garcia et al., 2010).

The Cape Floral Kingdom hosts more than 9000 plant species. Even though over 3000 of these indigenous plant species have ethnobotanical applications (Van Wyk et al., 1997), indigenous South African plants have not been systematically screened for novel endophytic micro-organisms. A novel actinomycete, $\mathrm{TVU}_{1}^{\mathrm{T}}$, was isolated from leaves of the bulbous plant Tulbaghia violacea, which is a member of the onion family, Alliaceae (Manning, 2003), during a screening programme of indigenous plants.

Leaves from $T$. violacea (wild garlic) were collected from an indigenous suburban garden in Wellington, approximately $60 \mathrm{~km}$ from Cape Town. The leaves were placed in sterile plastic bags, stored at $4{ }^{\circ} \mathrm{C}$ and processed within $24 \mathrm{~h}$ of collection. The identity of the plant species was confirmed from Joffe (1993). Leaves were initially surface-sterilized by placing them in $70 \%$ ethanol for $1 \mathrm{~min}$, then soaking them in $1 \%(\mathrm{v} / \mathrm{v}) \mathrm{NaOCl}$ for $3 \mathrm{~min}$, followed by rinsing twice in sterile distilled water. The surface-sterilized leaves were cut into $1 \mathrm{~cm}$ segments with sterile flamed scissors (Okazaki, 2003) and placed in a test tube containing $20 \mathrm{ml}$ quarterstrength sterile phosphate buffer [full-strength phosphate 
buffer $(0.05 \mathrm{M})$ contained $5.62 \mathrm{~g} \mathrm{~K}_{2} \mathrm{HPO}_{4}$ and $2.13 \mathrm{~g}$ $\mathrm{KH}_{2} \mathrm{PO}_{4}$, distilled water to $1 \mathrm{l}$, adjusted to $\mathrm{pH} 7$, autoclaved (Demain \& Davies, 1999)], vortexed briefly and incubated at $30{ }^{\circ} \mathrm{C}$ for $30 \mathrm{~min}$ with agitation. The phosphate buffer leaf extract was serially diluted with sterile distilled water and a $100 \mu \mathrm{l}$ aliquot of each dilution was spread-plated onto plant extract agar ( $400 \mathrm{ml}$ plant extract, $8.5 \mathrm{~g}$ glucose, $4.5 \mathrm{~g}$ yeast extract and $17.5 \mathrm{~g}$ agar, water to $1 \mathrm{l}, \mathrm{pH}$ 6.6-6.8, autoclaved). The plant extract was prepared by placing $160 \mathrm{~g}$ cut-up $T$. violacea plant leaves in $1.2 \mathrm{l}$ distilled water, bringing it to the boil and simmering for $30 \mathrm{~min}$. The liquid was cooled, filtered through two coffee filters (House of Coffees, size $1 \times 6$; Perco) and stored in a sterile glass bottle at $-20{ }^{\circ} \mathrm{C}$ (method adapted from Demain \& Davies, 1999). The isolation medium was supplemented with nalidixic acid $\left(10 \mu \mathrm{g} \mathrm{ml}^{-1}\right)$ and cycloheximide $\left(50 \mu \mathrm{g} \mathrm{ml}^{-1}\right)$. The isolation plates were incubated at $28{ }^{\circ} \mathrm{C}$ for 14 days. Isolates were selected based on morphology and subcultured onto plant extract agar (without antibiotics) and incubated at $30{ }^{\circ} \mathrm{C}$ for 7 days.

Morphological and physiological testing was performed according to the methods of Shirling \& Gottlieb (1966) and Williams et al. (1989). Unless stated otherwise, all plates were incubated at $30{ }^{\circ} \mathrm{C}$ for the recommended periods. The colours of the substrate mycelium and spore mass, as well as the production of diffusible pigments, were determined on yeast extract-malt extract agar (International Streptomyces Project medium no. 2, ISP 2; Shirling \& Gottlieb, 1966). Utilization of carbon sources was tested according to the method of Shirling \& Gottlieb (1966). All carbon sources were filter-sterilized and tested at $1 \%(\mathrm{w} / \mathrm{v})$. Salt tolerance was tested on ISP 2; plates were incubated at $30{ }^{\circ} \mathrm{C}$ for 14 days. Antibiotic susceptibility was tested by incorporating the filter-sterilized antibiotics into sterile Bennett's medium (Atlas, 1993) to the final concentrations stated in the species description.

To test growth on potato slices, one small potato was cut into $1 \times 1 \mathrm{~cm}$ blocks and half of the blocks were placed in a glass bottle and autoclaved. The remaining blocks were placed in a bottle containing approximately $5 \mathrm{~g} \mathrm{CaCO}_{3}$, shaken to mix and then autoclaved. Potato slices were placed in sterile Petri dishes and inoculated with $50 \mu \mathrm{l}$ spore suspension. Plates were sealed with Parafilm to prevent dehydration of the potato slices and incubated at $28{ }^{\circ} \mathrm{C}$ for 14 days.

Growth under anaerobic conditions was tested on carbon utilization agar (ISP 9; Shirling \& Gottlieb, 1966) with glucose as the sole carbon source and on ATCC medium 172 (http://www.lgcstandards-atcc.org/Attachments/2915. pdf) with the exception that the $\mathrm{N}-\mathrm{Z}$ amine type A was substituted with Casitone (Difco). When the plates were initially placed in the anaerobic chamber, they were each opened for $5 \mathrm{~s}$ to ensure that all residual $\mathrm{O}_{2}$ was removed before being sealed in a plastic bag. Plates were incubated anaerobically at $25{ }^{\circ} \mathrm{C}$ for 21 days (model 1024 anaerobic chamber; Forma Scientific) in an atmosphere comprising $5 \% \mathrm{H}_{2}: 10 \% \mathrm{CO}_{2}: 85 \% \mathrm{~N}_{2}$.
For scanning electron microscopy, cultures were grown on ISP 2 agar for 14 days at $28{ }^{\circ} \mathrm{C}$. Agar blocks containing sporulating vegetative mycelium were cut from the growth medium and frozen in liquid nitrogen prior to viewing by cryo-scanning electron microscopy.

Antimicrobial activity against Enterococcus faecium (VanA, clinical isolate), Escherichia coli ATCC 25922, Mycobacterium aurum A+ and Staphylococcus aureus ATCC 25923 was assessed on 11-day-old stab-inoculated actinomycete cultures by standard agar overlays. Strain TVU1 $^{\mathrm{T}}$ was stab-inoculated into ISP 2 agar, Czapek's solution agar (Atlas, 1993) and Difco Middlebrook 7H9 agar (Becton Dickinson) supplemented with $10 \mathrm{mM}$ glucose (ADC supplement omitted) and incubated at $30{ }^{\circ} \mathrm{C}$ for 11 days.

For chemotaxonomic analysis, the isolate was grown in $100 \mathrm{ml}$ ISP 2 broth for 5 days at $30{ }^{\circ} \mathrm{C}$ with shaking. The cell mass was collected by centrifugation, washed twice with $100 \mathrm{ml}$ sterile distilled water and freeze-dried. For diaminopimelic acid analysis, samples were prepared according to the method of Staneck \& Roberts (1974) and analysed according to the method of Hasegawa et al. (1983). A modified version of the Hasegawa et al. (1983) method was used for sugar analysis. The solvent system used for sugar analysis was ethyl acetate/pyridine/water (100:35:25, by vol.).

Genomic DNA was extracted as described previously (Wood et al., 2007). 16S rRNA gene amplification was performed as described by Cook \& Meyers (2003). For rapid genus identification, the resulting amplicons were restricted singly with MboI (isoschizomer of Sau3AI), VspI (isoschizomer of AsnI), SphI, SnaBI and SalI according to the method of Cook \& Meyers (2003). The amplified $16 \mathrm{~S}$ rRNA gene was purified with an MSB Spin PCRapace kit (Invitek). Sequencing reactions were performed using a Big Dye terminator v3.1 Cycle Sequencing kit (Applied Biosystems) and analysed on an Applied Biosystems 3130 Genetic Analyzer. Local alignments were obtained by performing a standard nucleotide-nucleotide BLAST search (BLASTN) (Altschul et al., 1997) of GenBank. For phylogenetic analysis, sequences were aligned using CLUSTAL_X version 1.81 (Thompson et al., 1997). Neighbour-joining (Saitou \& Nei, 1987), minimum-evolution (Rzhetsky \& Nei, 1993) and maximum-parsimony (Fitch, 1971) trees were constructed using MEGA version 3.1 (Kumar et al., 2004). DNA-DNA hybridization was performed by the Deutsche Sammlung von Mikroorganismen und Zellkulturen (DSMZ) GmbH Identification Service (Braunschweig, Germany) using the spectrophotometric method of De Ley et al. (1970), incorporating the modifications described by Huß et al. (1983). The results reported are the mean values from two hybridization experiments \pm standard deviation.

The $g y r B$ gene was amplified as two overlapping fragments (covering a total of approximately $1.5 \mathrm{~kb}$ ) using primers 7G-gyrB-F (le Roes et al., 2008) + KgyrB-R and GgyrBF2 + 7G-gyrB-R (Everest \& Meyers, 2009). Primer KgyrB-R 
(5'-CGATCCGGGCCTTCTCGACGTTCAG-3') was based on the partial gyrB sequences from Kribbella alba DSM $15500^{\mathrm{T}} \quad$ (EU434820), Kribbella antibiotica DSM $15501^{\mathrm{T}}$ (EU434819) and Kribbella solani CIP $108508^{\mathrm{T}}$ (EU434813); primer GgyrB-F2 (5'-CAGTTCGAGGGHCAGACSAAGAC$3^{\prime}$ ) was modified from primer GYRBF2 of Shen et al. (2006). To ensure that none of the primers would amplify the $g y r B$ paralogue ( $p a r E$ ), all primers were aligned with the parE gene sequences from Corynebacterium glutamicum ATCC $13032^{\mathrm{T}}$ (BA000036), Streptomyces avermitilis MA- $4680^{\mathrm{T}}$ (BA000030) and Streptomyces griseus subsp. griseus NBRC 13350 (AP009493). PCR was carried out in $50 \mu \mathrm{l}$ reaction volumes. Each reaction contained $4 \mathrm{mM} \mathrm{MgCl}_{2}, 0.1 \mathrm{U}$ SuperTherm Taq polymerase (JMR Holdings), $150 \mu \mathrm{M}$ of each dNTP, $0.5 \mu \mathrm{M}$ of each primer and 500-1000 ng template DNA. The PCR programme used was an initial denaturation at $96{ }^{\circ} \mathrm{C}$ for $2 \mathrm{~min}$, followed by 30 cycles of denaturation $\left(96^{\circ} \mathrm{C}\right.$ for $\left.45 \mathrm{~s}\right)$, annealing $\left(56{ }^{\circ} \mathrm{C}\right.$ for $\left.30 \mathrm{~s}\right)$ and extension $\left(72{ }^{\circ} \mathrm{C}\right.$ for $\left.2 \mathrm{~min}\right)$, and a final extension at $72{ }^{\circ} \mathrm{C}$ for $5 \mathrm{~min}$. PCR products were electrophoresed on $1 \%$ agarose gels containing $0.8 \mu \mathrm{g}$ ethidium bromide $\mathrm{ml}^{-1}$ and visualized on a GelDoc XR System (Bio-Rad). The resulting amplicons were purified and sequenced as described above.

According to the rapid genus identification method of Cook \& Meyers (2003), the isolate was identified as belonging to the genus Micromonospora. A standard 16S rRNA gene BLASTN search of GenBank showed that strain TVU1 ${ }^{\mathrm{T}}$ (1435 bp) was most closely related to $M$. echinospora ATCC $15837^{\mathrm{T}}$ (99.4\% similarity), but the phylogenetic tree showed that there was low bootstrap support $(42 \%)$ for this association (Fig. 1; a phylogenetic tree containing all recognized species of the genus Micromonospora is shown in Supplementary Fig. S1, available in IJSEM Online). The 16S rRNA gene sequence similarities between strain $\mathrm{TVU}^{\mathrm{T}}$ and Micromonospora chalcea NBRC $13503^{\mathrm{T}}$, Micromonospora endolithica DSM
$44398^{\mathrm{T}}$ and Micromonospora rosaria DSM $803^{\mathrm{T}}$ were 99.28, 99.20 and $99.06 \%$, respectively. Sequence similarities to all other type strains of species of the genus Micromonospora were $<99 \%$. DNA-DNA hybridization studies showed that the DNA-DNA relatedness between strain $\mathrm{TVU}^{\mathrm{T}}$ and $M$. echinospora DSM $43816^{\mathrm{T}}$ was $7.6 \pm 4.5 \%$. Surprisingly, phylogenetic analysis of the gyrB gene showed that strain $\mathrm{TVU}^{\mathrm{T}}$ was most closely related to Micromonospora aurantiaca NBRC $16155^{\mathrm{T}}$ and M. chalcea NBRC $13503^{\mathrm{T}}$, supported by a bootstrap value of $100 \%$ (Fig. 2). The overall topologies of the $16 \mathrm{~S}$ rRNA gene and gyrB gene trees were different, with only the close relationship between $M$. aurantiaca NBRC $16155^{\mathrm{T}}$ and M. chalcea NBRC $13503^{\mathrm{T}}$ being maintained. As the overall topology of a tree can be affected by the number of sequences included in the analysis, a second $16 \mathrm{~S}$ rRNA gene tree (Supplementary Fig. S2, available in IJSEM Online) was constructed using only those strains included in the $\operatorname{gyrB}$ gene sequence analysis shown in Fig. 2. The topology of this smaller $16 \mathrm{~S}$ rRNA gene tree was similar to the 16S rRNA gene tree that included all type strains of the genus Micromonospora, thus indicating that the change in the closest relatives of strain TVU1 ${ }^{\mathrm{T}}$ between the 16S rRNA and $\operatorname{gyrB}$ gene trees was not a technical effect (i.e. not due to the number of sequences used in the analysis). This suggests that there has been horizontal transfer of the gyrB and/or 16S rRNA genes between members of the genus Micromonospora. A previous study by Kasai et al. (2000) found that within the genus Micromonospora, phylogenetic trees based on gyrB gene sequences were different from those based on the 16S rRNA gene. They determined that a gyrB-based genetic distance of 0.014 would correspond to $70 \%$ DNA-DNA relatedness and that the gyrB gene was superior at inferring intrageneric relationships (Kasai et al., 2000). However, if there has been horizontal transfer of the $\operatorname{gyrB}$ gene in this genus, the conclusion

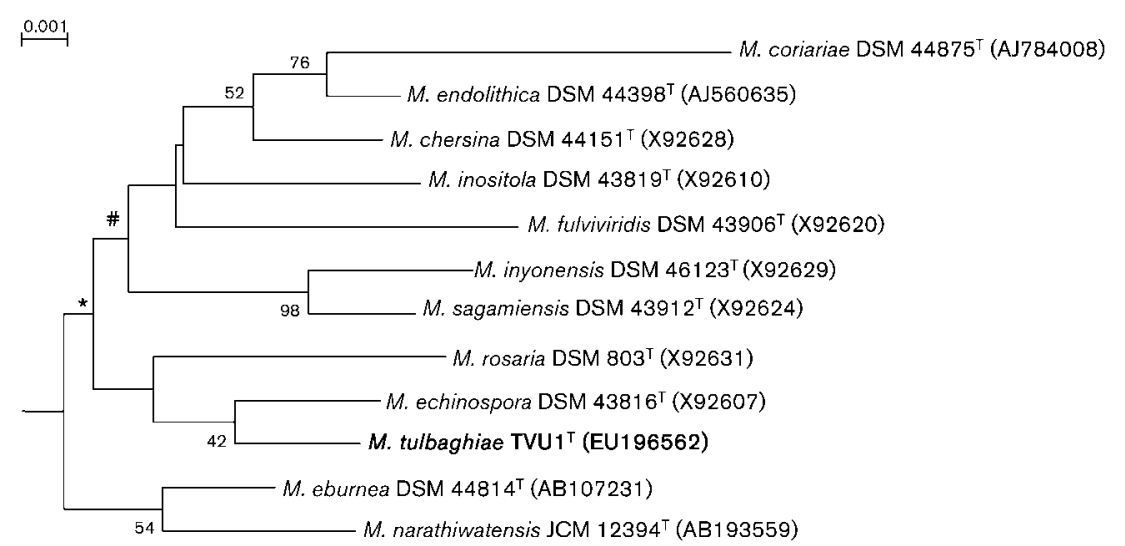

Fig. 1. Unrooted $16 \mathrm{~S}$ rRNA gene-based phylogenetic tree showing the relationship between strain $\mathrm{TVU}_{1}{ }^{\top}$ and its closest phylogenetic neighbours. The phylogenetic tree is based on $1398 \mathrm{bp}$ and was constructed using the neighbour-joining method. Bootstrap values are based on 1000 resampled datasets and only values $>40 \%$ are shown. Bar, $0.001 \mathrm{nt}$ substitutions per nucleotide site. The hash (\#) denotes the cluster that was conserved using the neighbour-joining (Saitou \& Nei, 1987), minimum-evolution (Rzhetsky \& Nei, 1993) and maximum-parsimony (Fitch, 1971) methods to construct the phylogenetic trees. The asterisk $\left(^{*}\right)$ denotes the cluster that was conserved using the neighbour-joining and minimum-evolution methods to construct the phylogenetic trees. 


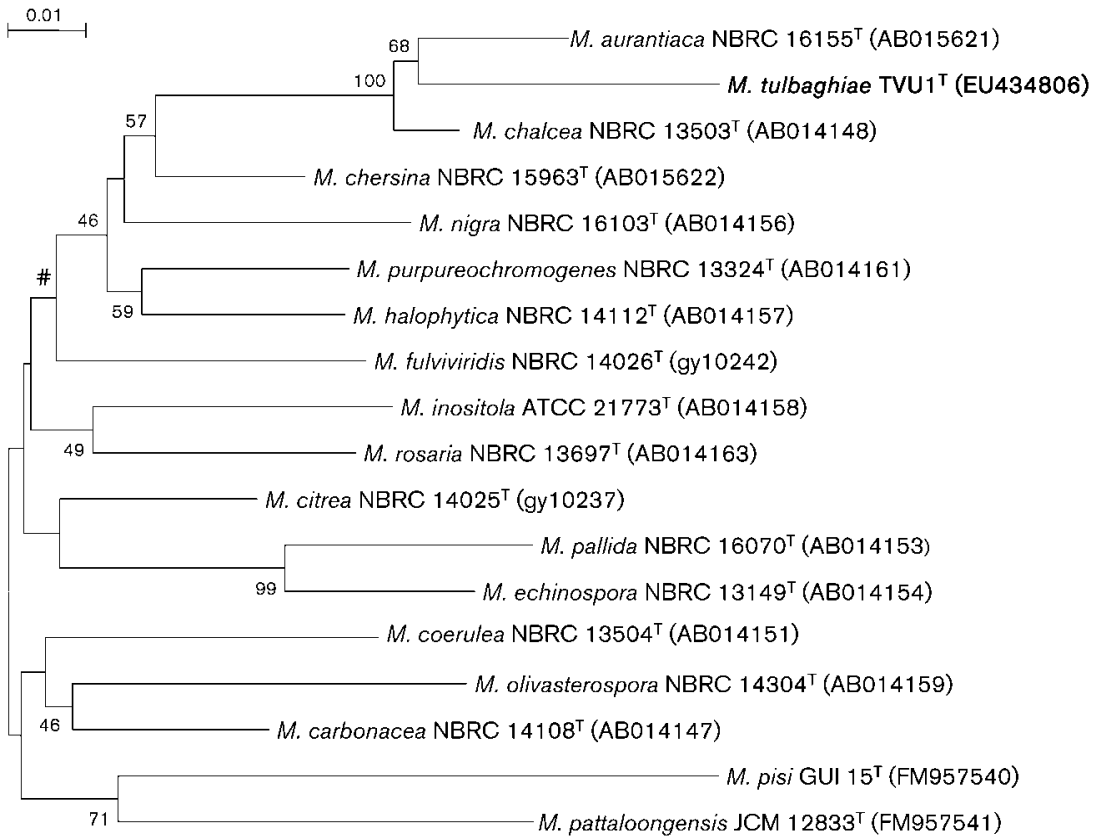

Fig. 2. Unrooted gyrB gene phylogenetic tree showing the relationship between strain $\mathrm{TVU}_{1}{ }^{\top}$ and all species of the genus Micromonospora with published $g y r B$ gene sequences. The phylogenetic tree is based on $935 \mathrm{bp}$ and was constructed using the neighbour-joining method. Bootstrap values are based on 1000 resampled datasets and only values $>40 \%$ are shown. Bar, $0.01 \mathrm{nt}$ substitutions per nucleotide site. The hash (\#) denotes the cluster that was conserved using the neighbour-joining (Saitou \& Nei, 1987), minimumevolution (Rzhetsky \& Nei, 1993) and maximum-parsimony (Fitch, 1971) methods to construct the phylogenetic trees.

that the $g y r B$ gene is more useful for determining interspecies relationships than the $16 \mathrm{~S}$ rRNA gene must be questioned. Indeed, it seems that multilocus sequence analysis of the entire genus will be necessary to gauge the extent of horizontal gene transfer in this genus and to assess the relationships between the recognized species. The gyrB-based genetic distance, determined using Kimura's two-parameter model (Kimura, 1980), between strain $\mathrm{TVU}^{\mathrm{T}}$ and $M$. aurantiaca NBRC $16155^{\mathrm{T}}$ was 0.022 , whereas the distance between strain $\mathrm{TVU}^{\mathrm{T}}$ and M. chalcea NBRC $13503^{\mathrm{T}}$ was 0.034 (i.e. well above the 0.014 threshold and therefore indicating that the DNADNA relatedness between these pairs of strains would be expected to be $<70 \%)$. To determine whether strain $\mathrm{TVU}^{\mathrm{T}}$ does indeed represent a distinct genomic species, DNA-DNA hybridization studies were performed between strain $\mathrm{TVU}^{\mathrm{T}}$ and the type strains of $M$. aurantiaca and $M$. chalcea. The DNA-DNA relatedness values of strain TVU1 ${ }^{\mathrm{T}}$ with $M$. aurantiaca DSM $43813^{\mathrm{T}}$ and $M$. chalcea DSM $43026^{\mathrm{T}}$ were $45.9 \pm 2.0$ and $60.9 \pm 4.5 \%$, respectively. These findings clearly distinguish strain TVU1 $^{\mathrm{T}}$ as a separate genomic species.

Strain TVU1 $1^{\mathrm{T}}$ was characterized by the presence of mesodiaminopimelic acid as the diagnostic diaminoacid of the cell-wall peptidoglycan and by the presence of glucose, ribose and xylose in its whole-cell hydrolysates. Morphologically, strain $\mathrm{TVU}^{\mathrm{T}}$ was characterized by the formation of medium brown vegetative mycelium on ISP 2 agar. The colonies became dark brown upon sporulation. Strain TVU1 ${ }^{\mathrm{T}}$ formed spores with smooth surfaces, which were on sporophores borne on the branching hyphae (Fig. 3 ). Selected physiological features that distinguish strain $\mathrm{TVU}^{\mathrm{T}}$ from $M$. aurantiaca NBRC $16155^{\mathrm{T}}, M$. chalcea
NBRC $13503^{\mathrm{T}}$, M. echinospora DSM $43816^{\mathrm{T}}$ and $M$. endolithica DSM $44398^{\mathrm{T}}$ are shown in Table 1. Additional physiological characteristics are reported in the species description.

\section{Description of Micromonospora tulbaghiae sp. nov.}

Micromonospora tulbaghiae (tul.ba.ghi'ae. N.L. gen. fem. n. tulbaghiae of/from Tulbaghia, the genus name of Tulbaghia violacea, the host of the organism).

Gram-stain-positive. Aerial mycelium is not formed. Substrate mycelium is medium brown on ISP 2 agar. Colonies become dark brown upon sporulation. Diffusible pigments are not produced. Grows on ISP 2 agar in the presence of $5 \%(\mathrm{w} / \mathrm{v}) \mathrm{NaCl}$. Degrades casein, gelatin, starch and Tween $80 . \mathrm{H}_{2} \mathrm{~S}$ is produced, but nitrate is not reduced. Grows at $4-37{ }^{\circ} \mathrm{C}$, but not at $45{ }^{\circ} \mathrm{C}$. Growth only

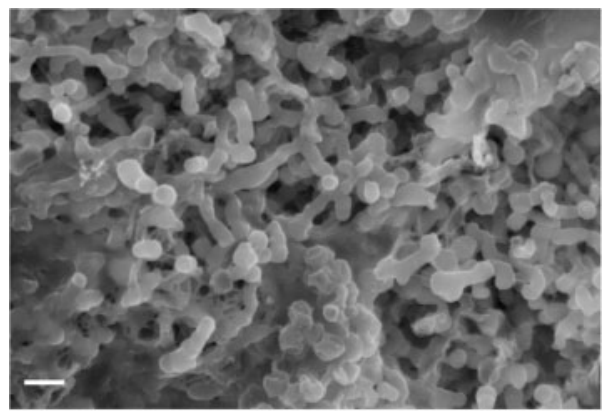

Fig. 3. Scanning electron micrograph of cells of strain $\mathrm{TVU}^{\mathrm{T}}$ grown on ISP 2 for 14 days at $28^{\circ} \mathrm{C}$. Bar, $1 \mu \mathrm{m}$. 
Table 1. Selected phenotypic characteristics that distinguish strain TVU1 ${ }^{\top}$ from related species of the genus $M i c r o m o n o s p o r a$

Strains: 1, Micromonospora tulbaghiae sp. nov. TVU1 ${ }^{\mathrm{T}}$ (data from this study); 2, M. echinospora DSM 43816 ${ }^{\mathrm{T}}$ (data from Kawamoto, 1989); 3 , M. aurantiaca ATCC $27029^{\mathrm{T}}$ (Thawai et al., 2004); 4, M. chalcea IFO $13503^{\mathrm{T}}$ (Kawamoto, 1989); 5, M. endolithica DSM 44398 ${ }^{\mathrm{T}}$ (Hirsch et al., 2004). $\mathrm{ND}$, Not determined; +, growth or positive reaction; w, weak; -, no growth or negative reaction; $\mathrm{v}$, variable results.

\begin{tabular}{|c|c|c|c|c|c|}
\hline Characteristic & 1 & 2 & 3 & 4 & 5 \\
\hline $\mathrm{NaCl}$ tolerance $(\%, \mathrm{w} / \mathrm{v})$ & 5 & $2^{*}$ & 4 & 5 & 7 \\
\hline Growth on potato & + & - & $\mathrm{ND}$ & + & $\mathrm{ND}$ \\
\hline Growth on potato $+\mathrm{CaCO}_{3}$ & - & - & ND & ND & $\mathrm{ND}$ \\
\hline $\mathrm{H}_{2} \mathrm{~S}$ production & + & - & ND & $\mathrm{ND}$ & - \\
\hline Nitrate reduction & - & - & + & $\mathrm{V}$ & - \\
\hline Starch hydrolysis & + & + & - & + & + \\
\hline \multicolumn{6}{|l|}{ Degradation of: } \\
\hline L-Tyrosine & - & - & + & - & + \\
\hline Xylan & $\mathrm{w}$ & $-{ }^{*}$ & $\mathrm{ND}$ & ND & - \\
\hline Growth temperature $\left({ }^{\circ} \mathrm{C}\right)$ & 4-37 & $27-37$ & $12-40$ & $27-45 \dagger$ & 8-39 \\
\hline Colony colour & Yellow-brown & Maroon-purple & $\mathrm{ND}$ & Red-orange $\dagger$ & Orange to olive \\
\hline Colour of diffusible pigment & None & Purple & $\mathrm{ND}$ & Yellow & None \\
\hline Spore colour & Dark brown & Brown-black & $\mathrm{ND}$ & $\mathrm{ND}$ & Black \\
\hline \multicolumn{6}{|c|}{ Utilization as sole carbon source: } \\
\hline$(+)$-L-Arabinose & - & + & $\mathrm{W}$ & $\mathrm{w}$ & + \\
\hline$(-)$-D-Fructose & + & - & + & $\mathrm{W}$ & + \\
\hline Glycerol & - & - & - & - & $\mathrm{ND}$ \\
\hline myo-Inositol & $\mathrm{W}$ & - & ND & - & - \\
\hline Lactose & - & - & - & + & + \\
\hline (-)-D-Mannitol & + & - & - & - & $\mathrm{w}$ \\
\hline Melibiose & - & - & + & + & + \\
\hline Raffinose & - & - & $\mathrm{w}$ & + & + \\
\hline$(+)$-L-Rhamnose & + & + & - & - & - \\
\hline$(-)$-D-Ribose & + & - & - & - & - \\
\hline (+)-D-Xylose & - & + & + & + & + \\
\hline \multicolumn{6}{|l|}{ Resistance to: } \\
\hline $\begin{array}{l}\text { Lincomycin hydrochloride } \\
\quad\left(100 \mu \mathrm{g} \mathrm{m}^{-1}\right)\end{array}$ & + & - & ND & ND & ND \\
\hline Rifampicin $\left(50 \mu \mathrm{g} \mathrm{ml}^{-1}\right)$ & + & - & ND & ND & ND \\
\hline
\end{tabular}

${ }^{*}$ Results determined in this study.

$\dagger$ Data from Horan \& Brodsky (1986).

occurs at $\mathrm{pH} 7-9$ on ISP 2. (-)-D-Fructose, (+)-Dglucose, myo-inositol (weakly), (-)-D-mannitol, $(+)$-Lrhamnose and $(-)$-D-ribose are utilized as sole carbon sources. (+)-L-Arabinose, cellobiose, glycerol, (-)-Dlactose, melibiose, raffinose, salicin and $(+)$-D-xylose are not utilized. Susceptible to $\left(\mathrm{ml}^{-1}\right)$ cephaloridine $(100 \mu \mathrm{g})$ and vancomycin hydrochloride $(50 \mu \mathrm{g})$, but resistant to kanamycin $(10 \mu \mathrm{g})$, lincomycin hydrochloride $(100 \mu \mathrm{g})$, oleandomycin phosphate $(100 \mu \mathrm{g})$, penicillin $\mathrm{G}(10 \mathrm{U})$ and rifampicin $(50 \mu \mathrm{g})$. Utilizes $\left(\mathrm{NH}_{4}\right)_{2} \mathrm{HPO}_{4}$, L-cysteine, gelatin, L-glutamine, L-histidine, L-isoleucine, L-leucine, Lmethionine and L-valine as sole nitrogen sources. Does not utilize DL- $\alpha$-alanine, $\beta$-alanine, DL- $\alpha$-amino- $n$-butyric acid, L-arginine, L-aspartic acid, L-glutamic acid, L-hydroxyproline, D-leucine, DL- $\beta$-phenylalanine, $\mathrm{KNO}_{3}, \mathrm{~L}$-proline, $\mathrm{NaNO}_{3}$ or L-serine as sole nitrogen sources. Weak growth occurs on ATCC 172 medium under anaerobic conditions over 21 days at $25{ }^{\circ} \mathrm{C}$; no growth occurs on ISP 9 under anaerobic conditions. Moderate antibiosis is observed against Mycobacterium aurum $\mathrm{A}+$.

The type strain, TVU1 $^{\mathrm{T}} \quad\left(=\mathrm{DSM} \quad 45142^{\mathrm{T}}=\mathrm{NRRL}\right.$ $\left.\mathrm{B}-24576^{\mathrm{T}}\right)$, was isolated from leaves of wild garlic, Tulbaghia violacea.

\section{Acknowledgements}

The authors wish to thank Di James for DNA sequencing and Miranda Waldron of the Electron Microscope Unit, University of Cape Town (UCT), for assistance with scanning electron microscopy. We thank Professor Hans G. Trüper for his assistance in deriving the specific name for the isolate and Associate Professors Shez Reid and Val Abratt for use of the anaerobic chamber. B. K. held a Scarce Skills Scholarship from the National Research Foundation (NRF) and a UCT Postgraduate Research Associateship. This work was supported 
by research grants to P. R.M. from the Medical Research Council of South Africa, the NRF (grant number 2073133) and the University Research Committee (UCT).

\section{References}

Altschul, S. F., Madden, T. L., Schäffer, A. A., Zhang, J., Zhang, Z., Miller, W. \& Lipman, D. J. (1997). Gapped BLAST and PSI-BLAST: a new generation of protein database search programs. Nucleic Acids Res 25, 3389-3402.

Atlas, R. M. (1993). Handbook of Microbiological Media. Edited by L. C. Parks. Boca Raton, FL: CRC Press.

Cook, A. E. \& Meyers, P. R. (2003). Rapid identification of filamentous actinomycetes to the genus level using genus-specific $16 \mathrm{~S}$ rRNA gene restriction fragment patterns. Int J Syst Evol Microbiol 53, 1907-1915.

De Ley, J., Cattoir, H. \& Reynaerts, A. (1970). The quantitative measurement of DNA hybridization from renaturation rates. Eur $J$ Biochem 12, 133-142.

Demain, A. L. \& Davies, J. E. (editors) (1999). Manual of Industrial Microbiology and Biotechnology, 2nd edn. Washington, DC: American Society for Microbiology.

Everest, G. J. \& Meyers, P. R. (2009). The use of gyrB sequence analysis in the phylogeny of the genus Amycolatopsis. Antonie van Leeuwenhoek 95, 1-11.

Fitch, W. M. (1971). Toward defining the course of evolution: minimum change for a specific tree topology. Syst Zool 20, 406-416.

Garcia, L. C., Martínez-Molina, E. \& Trujillo, M. E. (2010). Micromonospora pisi sp. nov., isolated from root nodules of Pisum sativum. Int J Syst Evol Microbiol 60, 331-337.

Hasegawa, T., Takizawa, M. \& Tanida, S. (1983). A rapid analysis for chemical grouping of aerobic actinomycetes. J Gen Appl Microbiol 29, 319-322.

Hirsch, P., Mevs, U., Kroppenstedt, R. M., Schumann, P. \& Stackebrandt, E. (2004). Cryptoendolithic actinomycetes from Antarctic sandstone rock samples: Micromonospora endolithica sp. nov. and two isolates related to Micromonospora coerulea Jensen 1932. Syst Appl Microbiol 27, 166-174.

Horan, A. C. \& Brodsky, B. C. (1986). Micromonospora rosaria sp. nov., nom. rev., the rosaramicin producer. Int J Syst Bacteriol 36, 478-480.

Huß, V. A. R., Festl, H. \& Schleifer, K. H. (1983). Studies on the spectrophotometric determination of DNA hybridization from denaturation rates. Syst Appl Microbiol 4, 184-192.

Joffe, P. (1993). The Gardener's Guide to South African Plants. Cape Town, South Africa: Tafelberg.

Kasai, H., Tamura, T. \& Harayama, S. (2000). Intrageneric relationships among Micromonospora species deduced from gyrB-based phylogeny and DNA relatedness. Int J Syst Evol Microbiol 50, 127-134. Kawamoto, I. (1989). Genus Micromonospora Ørskov 1923, $147^{\mathrm{AL}}$. In Bergey's Manual of Systematic Bacteriology, vol. 4, pp. 2442-2450. Edited by S. T. Williams, M. E. Sharpe \& J. G. Holt. Baltimore: Williams \& Wilkins.

Kimura, M. (1980). A simple method for estimating evolutionary rates of base substitutions through comparative studies of nucleotide sequences. J Mol Evol 16, 111-120.

Kumar, S., Tamura, K. \& Nei, M. (2004). MEGA3: integrated software for molecular evolutionary genetics analysis and sequence alignment. Brief Bioinform 5, 150-163. le Roes, M., Goodwin, C. M. \& Meyers, P. R. (2008). Gordonia lacunae sp. nov., isolated from an estuary. Syst Appl Microbiol 31, 17-23.

Manning, J. (2003). Photographic Guide to the Wildflowers of South Africa. Pretoria, South Africa: Briza Publications.

Okazaki, T. (2003). Studies on actinomycetes isolated from plant leaves. In Selective Isolation of Rare Actinomycetes, chapter 4. Edited by I. Kurtböke. Queensland, Australia: University of the Sunshine Coast.

Orskov, J. (1923). Investigations into the Morphology of the Ray Fungi. Copenhagen: Levin and Munksgaard.

Rzhetsky, A. \& Nei, M. (1993). Theoretical foundation of the minimum-evolution method of phylogenetic inference. Mol Biol Evol 10, 1073-1095.

Saitou, N. \& Nei, M. (1987). The neighbor-joining method: a new method for reconstructing phylogenetic trees. Mol Biol Evol 4, 406425.

Shen, F.-T., Lu, H.-L., Lin, J.-L., Huang, W.-S., Arun, A. B. \& Young, C.-C. (2006). Phylogenetic analysis of members of the metabolically diverse genus Gordonia based on proteins encoding the gyrB gene. Res Microbiol 157, 367-375.

Shirling, E. B. \& Gottlieb, D. (1966). Methods for characterization of Streptomyces species. Int J Syst Bacteriol 16, 313-340.

Staneck, J. L. \& Roberts, G. D. (1974). Simplified approach to identification of aerobic actinomycetes by thin-layer chromatography. Appl Microbiol 28, 226-231.

Thawai, C., Tanasupawat, S., Itoh, T., Suwanborirux, K. \& Kudo, T. (2004). Micromonospora aurantionigra sp. nov., isolated from a peat swamp forest in Thailand. Actinomycetologica 18, 8-14.

Thawai, C., Tanasupawat, S., Itoh, T., Suwanborirux, K. \& Kudo, T. (2005). Micromonospora siamensis sp. nov., isolated from Thai peat swamp forest. J Gen Appl Microbiol 51, 229-234.

Thompson, J. D., Gibson, T. J., Plewniak, F., Jeanmougin, F. \& Higgins, D. G. (1997). The CLUSTAL_X windows interface: flexible strategies for multiple sequence alignment aided by quality analysis tools. Nucleic Acids Res 25, 4876-4882.

Trujillo, M. E., Fernández-Molinero, C., Velázquez, E., Kroppenstedt, R. M., Schumann, P., Mateos, P. F. \& Martínez-Molina, E. (2005). Micromonospora mirobrigensis sp. nov. Int J Syst Evol Microbiol 55, 877-880.

Trujillo, M. E., Kroppenstedt, R. M., Schumann, P., Carro, L. \& Martínez-Molina, E. (2006). Micromonospora coriariae sp. nov., isolated from root nodules of Coriaria myrtifolia. Int J Syst Evol Microbiol 56, 2381-2385.

Trujillo, M. E., Kroppenstedt, R. M., Fernández-Molinero, C., Schumann, P. \& Martínez-Molina, E. (2007). Micromonospora lupini sp. nov., and Micromonospora saelicesensis sp. nov., isolated from root nodules of Lupinus angustifolius. Int J Syst Evol Microbiol 57, 2799-2804.

Van Wyk, B.-E., Van Oudtshoorn, B. \& Gericke, N. (1997). Medicinal Plants of South Africa. Pretoria, South Africa: Briza Publications.

Wagman, G. H. \& Weinstein, M. J. (1980). Antibiotic from Micromonospora. Annu Rev Microbiol 34, 537-557.

Williams, S. T., Goodfellow, M. \& Alderson, G. (1989). Genus Streptomyces Waksman and Henrici 1943, 339 ${ }^{\mathrm{AL}}$. In Bergey's Manual of Systematic Bacteriology, vol. 4, pp. 2452-2492. Edited by S. T. Williams, M. E. Sharpe \& J. G. Holt. Baltimore: Williams \& Wilkins.

Wood, S. A., Kirby, B. M., Goodwin, C. M., Le Roes, M. \& Meyers, P. R. (2007). PCR screening reveals unexpected antibiotic biosynthetic potential in Amycolatopsis sp. strain UM16. J Appl Microbiol 102, 245253. 